\title{
PENINGKATAN EFISIENSI PRODUKSI SAGON BAKAR SKALA INDUSTRI RUMAH TANGGA
}

\author{
Increasing Production Efficiency of Baked Sagon in Household Scale Industry \\ Panji Deoranto ${ }^{1)}$, Retno Astuti ${ }^{1)}$ \\ ${ }^{1)}$ Jurusan Teknologi Industri Pertanian \\ Fakultas Teknologi Pertanian - Universitas Brawijaya Jl. Veteran, Malang
}

\begin{abstract}
Baked sagon has a delicious taste, creamy mouthfeel, crunchy, and good appearance. The processing of baked sagon has constraints in the inefficient process of wax rice milling, coconut grating, roasting, and baking. Mechanization of the productionbaked sagon is required to improve the efficiency of baked sagon production. Improved product quality consistency is done through the implementation of standard operating procedure (SOP) for each stage of processing sagon fuel. The results of the activities through the facilitation of production equipment, partners the opportunity to increase its production capacity and efficiency. Coconut grater can increase the efficiency of grating with a capacity of 0.5 coconuts/min or 30 coconuts/h. Mechanical milling implies in efficient waxy rice flour preparation with capacity of 50-100 kg/h. Mechanical roaster for waxy rice flour and grated coconut improves roasting capacity of $5 \mathrm{~kg} / \mathrm{batch}$. Roasting is a critical point and bottleneck in the production baked sagon. Oven increases the capacity of baking. Implementation of SOP can improve the consistency of product.
\end{abstract}

Keywords: baking, baked sagon, grating, milling, roasting, standard operating procedure

\begin{abstract}
ABSTRAK
Sagon bakar tersebut mempunyai cita rasa yang enak karena gurih, tidak keras, dan tampilan bagus. Proses pengolahan sagon bakar terkendala pada proses penepungan, pemarutan, penyangraian, dan pemanggangan yang tidak efisien. Mekanisasi proses produksi sagon bakar untuk proses penepungan, pemarutan, penyangraian, dan pemanggangan ditujukan untuk meningkatkan efisiensi produksi sagon bakar. Peningkatan konsistensi mutu produk dilakukan melalui penyusunan standard operating procedure (SOP) untuk setiap tahapan pengolahan sagon bakar. Hasil kegiatan melalui fasilitasi peralatan produksi, mitra berpeluang meningkatkan kapasitas dan efisiensi produksinya. Fasilitasi alat pemarut dapat mengefisienkan proses pemarutan kelapa muda dengan kapasitas 0,5 butir kelapa/menit atau 30 butir kelapa/jam. Adanya mekanisasi penepungan di tempat produksi mitra, menyebabkan proses penepnungan menjadi lebih efisien dengan kapasitas penepungan 50-100 kg/jam. Penyangraian merupakan tahapan proses yang selama ini dilakukan secara manual menggunakan wajan. Fasilitasi alat penyangrai mekanis untuk tepung ketan dan kelapa parut, meningkatkan efisiensi poduksi sagon bakar dengan kapasitas penyangraian $5 \mathrm{~kg} /$ batch dengan proses pengadukan mekanis. Pemanggangan merupakan titik kritis dan bottle neck pada proses produksi sagon bakar. Kapasitas pemanggangan yang kecil menyebabkan proses produksi menjadi lama. Fasilitasi 2 buah oven bertingkat meningkatkan kapasitas pemanggangan dan memungkinkan mitra melakukan diversifikasi produk. Adanya SOP dapat meningkatkan konsistensi mutu produk sagon bakar.
\end{abstract}

Kata kunci: pemarutan, pemanggangan, penepungan, penyangraian, sagon bakar, standard operating procedure 


\section{PENDAHULUAN}

Sagon bakar merupakan produk pangan olahan yang dibuat dari tepung beras ketan, kelapa muda parut, dan gula pasir. Pada proses pengolahannya, beras digling menjadi tepung kemudian disangrai. Demikian pula kelapa muda disangrai dan kemudian dicampurkan dengan tepung beras sangrai dan gula pasir. Selanjutnya campuran tersebut dicetak dan dioven. Di Kecamatan Kanigoro, Kabupaten Blitar, dilakukan pembagian sentra pangan olahan berdasarkan produksi pangan olahan dominan di suatu desa. Desa Jatinom merupakan desa sebagai sentra produksi sagon bakar. Sagon bakar diproduksi oleh banyak warga.

Proses pengolahan sagon bakar ini adalah sama dengan alat proses dan kendala yang sama. Mitra menggunakan alat penepung dan pemarut kelapa di pasar sehingga jika akan menepungkan beras dan memarut kelapa harus berangkat ke pasar. Untuk proses penepungan dan pemarutan memakan waktu lama karena untuk ke pasar memerlukan waktu. Proses penyangraian menggunakan wajan dan manual dengan kapasitas kecil sehingga proses penyangraian memakan waktu lama yaitu untuk satu resep dengan 5 butir kelapa membutuhkan waktu 1 jam. Penyangraian kelapa parut penting dilakukan untuk mendapatkan sagon bakar dengan daya tahan lama. Di dalam kelapa terdapat enzim lipase (Ejedegba et al., 2007) yang dapat berperan menghidrolisis lemak sehingga memicu ketengikan. Pemanasan melalui penyangraian berfungsi menginaktivasi lipase sehingga sagon bakar yang dihasilkan lebih tahan terhadap ketengikan. Penyangraian tepung ketan juga membutuhkan waktu lama yaitu untuk $5 \mathrm{~kg}$ membutuhkan waktu 1 jam. Permasalahan lain adalah pada proses pengovenan. Mitra menggunakan oven kecil kapasitas 3 loyang dan untuk satu batch pengovenan dibutuhkan waktu $1 / 2$ jam. Dalam satu kali produksi untuk $5 \mathrm{~kg}$ tepung ketan dibutuhkan pengovenan 5 jam. Kendalakendala tersebut menyebabkan mitra tidak bisa mengoptimalkan proses produksinya.

Peningkatan efisiensi produksi pada proses pemarutan, penepungan, penyangraian, dan pemanggangan perlu dilakukan melalui alih teknologi proses secara mekanis. Bimbingan dan pendampingan diperlukan untuk proses pengolahan yang standar sehingga walaupun orang yang memproduksi berbeda, produk yang dihasilkan bermutu sama. Proses pengolahan terstandar tersebut dapat dicapai jika mitra menerapak standard operating procedure (SOP) yang sama untuk setiap tahapan prosesnya.

\section{METODE PELAKSANAAN}

\section{Peningkatan kapasitas dan efisiensi produksi sagon bakar}

Mitra kelompok usaha sagon bakar selama ini belum mempunyai peralatan mekanis untuk proses produksinya. Semua peralatan berkapasitas kecil atau menyewa kepada orang lain seperti untuk pemarutan dan penepungan mitra menggunakan jasa pemarutan kelapa dan penepungan beras ketan di pasar. Hal ini menyebabkan waktu produksi menajdi tidak efisien karena harus ada alokasi waktu untuk ke pasar. Masingmasing mitra dalam satu kali produksi menghasilkan $5 \mathrm{~kg}$ sagon bakar yang dikemas seberat $200 \mathrm{~g}$ dan dijual Rp. 8.000/kemasan.

Proses pemarutan dan penepungan dapat diefisienkan jika mitra memiliki alat pemarut dan penepung sendiri. Pemarut dengan kapasitas $5 \mathrm{~kg} / \mathrm{jam}$ dapat membantu mitra untuk mengatasi masalah pemarutan yang tidak efisien.

Proses penepungan mengalami masalah yang sama dengan pemarutan. Mitra kesulitan melakukan penepungan karena tidak mempunyai alat penepung dan seringkali harus antri di pasar. Penepung sistem disc mill dengan kapasitas 50-75 $\mathrm{kg} / \mathrm{jam}$ akan sangat membantu mengatasi masalah mitra tersebut. 
Masalah lain yang dihadapi mitra adalah proses penyangraian kelapa dan tepung ketan yang lama. Penyangraian kelapa selama ini dilakukan menggunakan wajan kecil dengan kapasitas 5 butir kelapa. Untuk penyangraian 5 butir kelapa dibutuhkan waktu 1 jam secara manual. Hal ini menyebabkan proses tidak efisien dan memakan tenaga. Penyangraian tepung ketan dilakukan dalam waktu 30 menit untuk $5 \mathrm{~kg}$ tepung ketan. Mitra menyampaikan bahwa alat penyangrai kelapa dan tepung menjadi sangat penting untuk menghemat tenaga dan meningkatkan kapasitas produksi.

Permasalahan lain yang dimiliki mitra akibat keterbatasan modal adalah proses pemanggangan sagon bakar dengan oven kecil (Gambar 1) sehingga proses pengovenan ini memakan waktu yang paling lama. Untuk $5 \mathrm{~kg}$ bahan baku tepung ketan dengan kapasitas pengovenan $1 / 2 \mathrm{~kg} /$ batch atau $1 / 2$ jam dibutuhkan waktu pemanggangan 5 jam. Mitra mengharapkan ada fasilitasi peningkatan kapasitas pemanggangan dengan menggunakan oven 2 tingkat dengan kapasitas loyang besar.

\section{Pendampingan penyusunan dan implementasi SOP}

Salah satu target yang harus dicapai melalui program IbM ini adalah peningkatkan konsistensi mutu produk sagon bakar. Konsistensi mutu ini penting mengingat produk yang dihasilkan mitra merupakan produk bersama yang diproduksi oleh orang yang berbeda. Konsistensi mutu dapat dicapai salah satunya dengan penyusunan SOP untuk setiap tahapan produksi mitra. SOP yang sudah disusun tersebut harus diterjemahkan dari apa yang dilakukan mitra selama ini. Selanjutnya mitra perlu didampingi untuk implementasi SOP yang sudah disusun. Implementasi SOP harus dilakukan di semua mitra sehingga produk yang dihasilkan antar mitra menjadi konsisten.

\section{HASIL DAN LUARAN CAPAIAN}

\section{Peningkatan kapasitas dan efisiensi pro- duksi sagon bakar}

Peningkatan kapasitas dan efisiensi produksi sagon bakar dilakukan dengan fasilitasi peralatan mekanis sebagai berikut:

a. Peningkatan kapasitas pemarutan kelapa

b. Peningkatan kapasitas penepungan ketan

c. Peningkatan kapasitas penyangraian tepung ketan dan kelapa parut

d. Peningkatan kapasitas pengovenan

Proses pemarutan dan penepungan dapat diefisienkan jika mitra memiliki alat pemarut dan penepung sendiri. Pemarut kecil dengan kapasitas 0,5 butir/menit dapat membantu mitra untuk mengatasi masalah pemarutan yang tidak efisien. Alat pemarut dapat dilihat pada Gambar 1. Adanya alat pemarut ini menyebabkan mitra tidak perlu pergi ke pasar untuk memarut kelapa muda sehingga proses produksi lebih efisien.

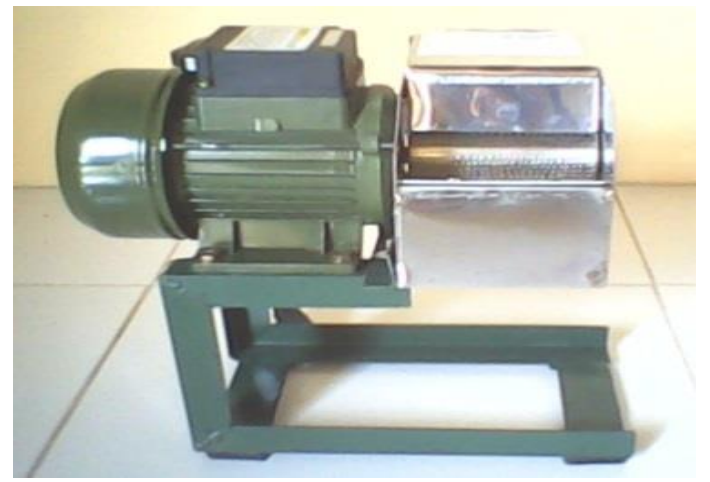

Gambar 1. Pemarut kelapa 


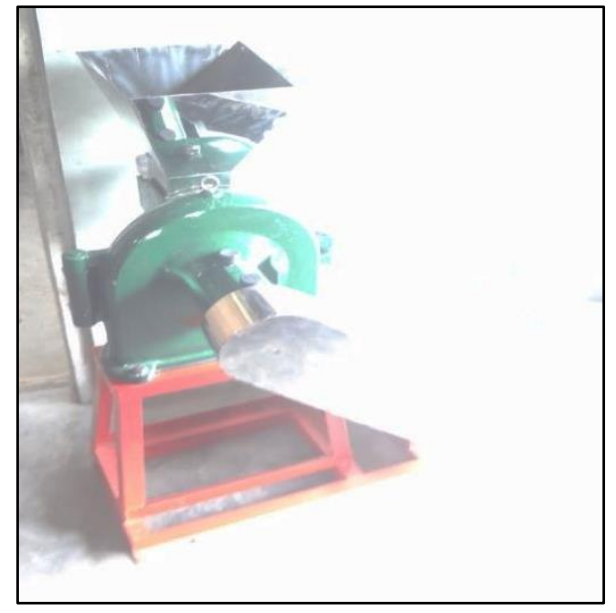

Gambar 2. Fasilitasi penepung ketan

Proses penepungan mengalami masalah yang sama dengan pemarutan. Mitra kesulitan melakukan penepungan karena tidak mempunyai alat penepung dan seringkali harus antri di pasar. Fasilitasi alat penepung dengan kapasitas 50-100 kg/jam dengan sistem disc mill (Gambar 2) dapat membantu mengatasi masalah mitra tersebut. Adanya penepung ini menyebabkan Mitra dapat meningkatkan kapasitas produksinya.

Masalah lain yang dihadapi mitra adalah proses penyangraian kelapa dan tepung ketan yang lama. Penyangraian kelapa selama ini dilakukan menggunakan wajan kecil dengan kapasitas 5 butir kelapa. Untuk penyangraian 5 butir kelapa dibutuhkan waktu 1 jam secara manual. Hal ini menyebabkan proses tidak efisien dan memakan tenaga. Penyangraian tepung ketan dilakukan dalam waktu 30 menit untuk $5 \mathrm{~kg}$ tepung ketan.
Permasalahan lain yang dimiliki mitra akibat keterbatasan modal adalah proses pemanggangan sagon bakar dengan oven kecil sehingga proses pengovenan ini memakan waktu yang paling lama. Untuk 5 $\mathrm{kg}$ bahan baku tepung ketan dengan kapasitas pengovenan $1 / 2 \mathrm{~kg} /$ batch atau $1 / 2$ jam dibutuhkan waktu pemanggangan 5 jam. Pada program ini dilakukan fasilitasi oven gas 2 tingkat (Gambar 3) sebanyak 2 buah masing-masing untuk peningkatan kapasitas produksi sagon bakar. Oven yang dilengkapi dengan pengatur suhu akan sangat membantu mitra untuk mengendalikan proses pemanggangan sehingga mutu produk sagon menjadi seragam. Oven ini mempunyai kapasitas 4 buah loyang ukuran 40 X $60 \mathrm{~cm}$ dengan api dapat diatur. Sistem perapian 2 bagian yaitu api atas dan api bawah sehingga proses pemanggangan sagon bakar bisa lebih merata.
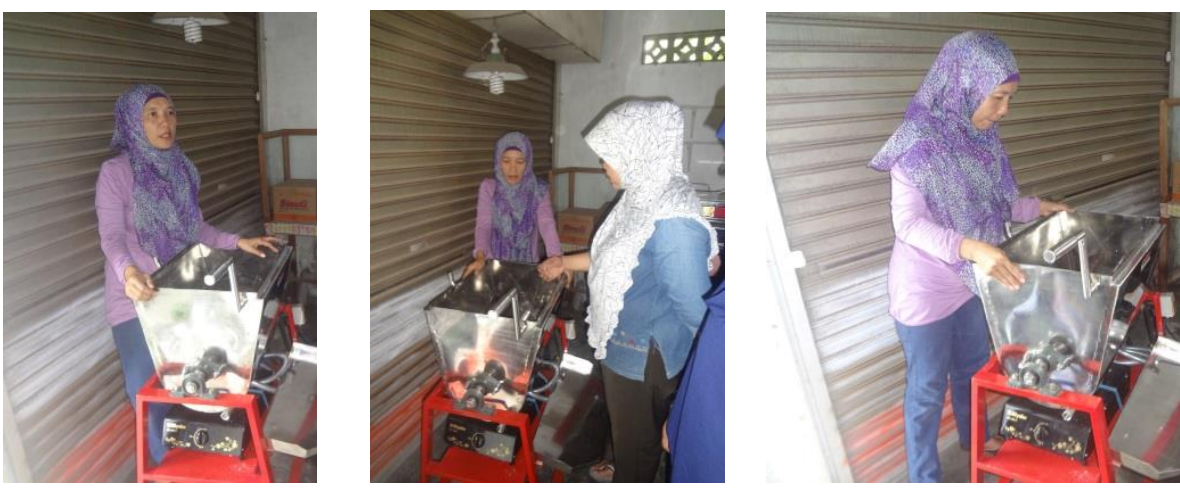

Gambar 2. Alat penyangrai 

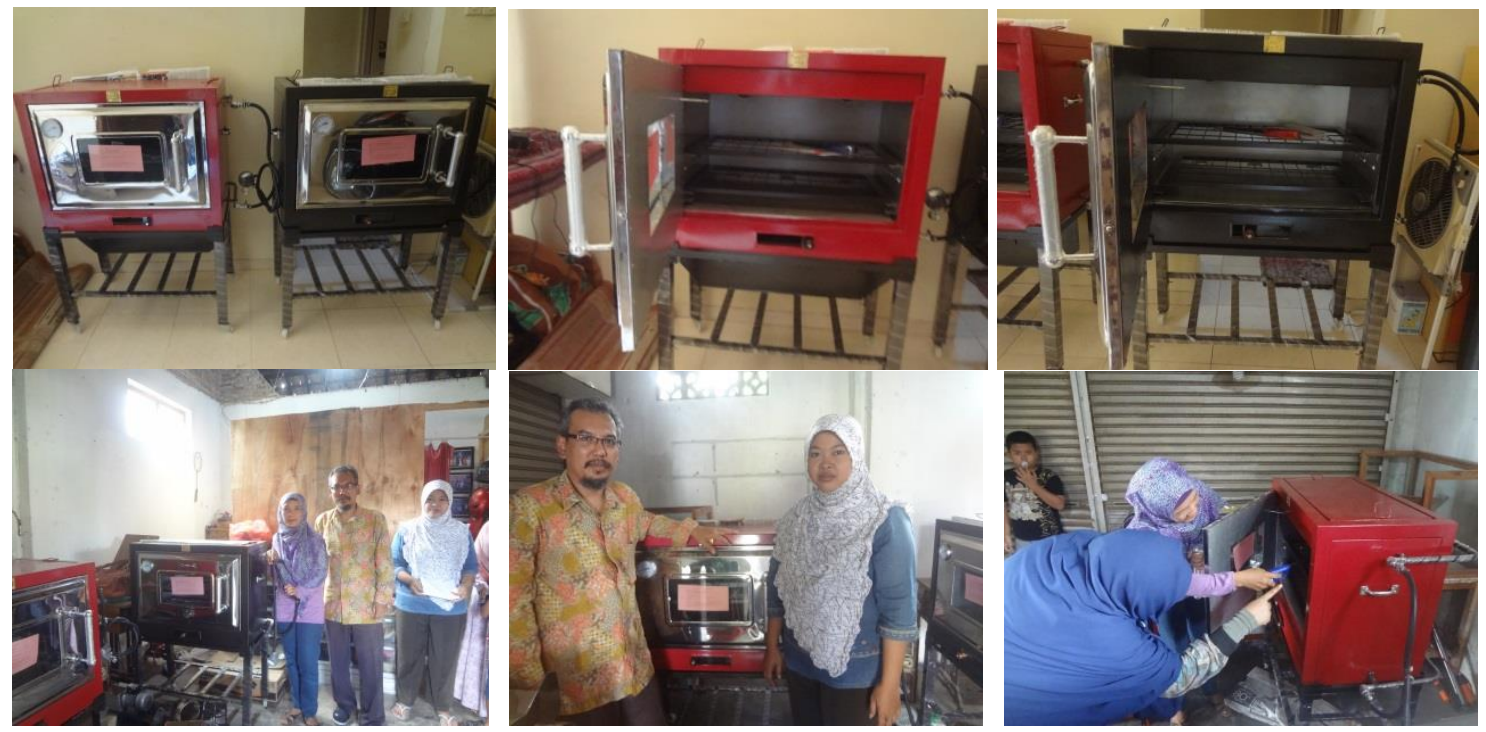

Gambar 3. Oven pemanggang 2 tingkat

Tabel 1. Capaian program peningkatan kapasitas dan efisiensi produksi sagon bakar

\begin{tabular}{lll}
\hline No. & \multicolumn{1}{c}{ Program } & \multicolumn{1}{c}{ Capaian } \\
\hline 1. & $\begin{array}{l}\text { Peningkatan kapasitas dan efisiensi } \\
\text { pemarutan }\end{array}$ & Waktu pemarutan $1 / 2$ butir kelapa/menit \\
2. & $\begin{array}{l}\text { Peningkatan kapasitas dan efisiensi } \\
\text { penepungan }\end{array}$ & Waktu penepungan $50-100 \mathrm{~kg} / \mathrm{jam}$ \\
3. & $\begin{array}{l}\text { Peningkatan kapasitas dan efisiensi } \\
\text { penyangraian }\end{array}$ & Waktu penyangraian $5 \mathrm{~kg} / \mathrm{jam}$ \\
4. & $\begin{array}{l}\text { Peningkatan kapasitas } \\
\text { pemanggangan }\end{array}$ & Peningkatan kapasits pemanggangan dari \\
& $1 \mathrm{~kg} / \mathrm{jam}$ menjadi $10 \mathrm{~kg} / \mathrm{jam}$
\end{tabular}

Mekanisasi proses produksi untuk mitra Kelompok Usaha Sagon Bakar diharapkan dapat mengefisienkan proses produksi disamping meningkatkan kapasitas produksi setelah program dapat dilihat pada Tabel 1. Capaian lain dengan adanya fasilitasi alat ini dalah proses lebih terkendali sehingga mutu produk lebih seragam. Adanya alat mekanis akan lebih memudahkan untuk pengendalian proses.

\section{Pendampingan penyusunan dan imple- mentasi SOP}

Salah satu target yang harus dicapai melalui program IbM ini adalah peningkatkan konsistensi mutu produk sagon bakar. Konsistensi mutu ini penting mengingat produk yang dihasilkan mitra merupakan produk bersama yang diproduksi oleh orang yang berbeda. Konsistensi mutu dapat dicapai salah satunya dengan penyusunan SOP untuk setiap tahapan produksi mitra. SOP yang disusun akan diterjemahkan dari apa yang dilakukan mitra selama ini meliputi SOP untuk pemilihan bahan baku, pemarutan kelapa, pemarutan kelapa, penyangraian kelapa, penepungan beras ketan, penyangraian tepung beras ketan, pencampuran bahan, pencetakan, pemanggangan, dan pengemasan.

\section{KESIMPULAN}

Hasil kegiatan melalui fasilitasi peralatan produksi, mitra berpeluang meningkatkan kapasitas dan efisiensi produksinya. Fasilitasi alat pemarut dapat mengefisienkan proses pemarutan kelapa muda dengan kapasitas 0,5 butir kelapa/ menit atau 30 butir kelapa/jam. Adanya me- 
kanisasi penepungan di tempat produksi mitra, menyebabkan proses penepnungan menjadi lebih efisien dengan kapasitas penepungan $50-100 \mathrm{~kg} / \mathrm{jam}$. Penyangraian merupakan tahapan proses yang selama ini dilakukan secara manual menggunakan wajan. Fasilitasi alat pe-nyangrai mekanis untuk tepung ketan dan kelapa parut, meningkatkan efisiensi poduksi sagon bakar dengan kapasitas penyangraian $5 \mathrm{~kg} /$ batch dengan proses pengadukan mekanis. Pemanggangan me-rupakan titik kritis dan bottle neck pada proses produksi sagon bakar. Kapasitas pe-manggangan yang kecil menyebabkan proses produksi menjadi lama. Fasilitasi 2 buah oven bertingkat meningkatkan kapasitas pemanggangan dan me-mungkinkan mitra melakukan diversifikasi produk.

\section{UCAPAN TERIMA KASIH}

Penulis mengucapkan terma kasih yang sebesar-besarnya kepada Direktorat Penelitian dan Pengabdian kepada Masyarakat, Direktorat Jenderal Pendidikan Tinggi, Kementerian Riset, Teknologi dan Pendidikan Tinggi atas pendanaan kegiatan melalui skim Iptek bagi Masyarakat (IbM) Tahun 2016 dengan Nomor Penugasan: 019/SP2H/ PPM/DRPM/II/2016 tanggal 18 Februari 2016, serta Lembaga Penelitian dan Pengabdian kepada Masyarakat (LPPM) Universitas Brawijaya.

\section{DAFTAR PUSTAKA}

Ejdegba $\mathrm{B} \mathrm{O}, \mathrm{E}$ Onyeneke and $\mathrm{P} \mathrm{O}$ Oviasogie. (2007). Characteristics of lipase isolated from coconut (Cocosnucifera linn) seed under different nutrient treatments. African Journal of Biotechnology 6(6):723727 